\title{
Impact of UNDP's Initiated Projects on Socio-Economic Development of Women: A Study of Rural Punjab, Pakistan
}

\author{
R.D. Nisar \\ Central China Normal University \\ No. 152, Luoyu Road, 430079, Wuhan, Hubei, People's Republic of China
}

\begin{abstract}
Women are half of the world's total population. Their condition around the globe is drastic. Women's empowerment is much underscore issue of the $21^{\text {st }}$ century. The West, which got phenomenal prosperity, is a direct result of empowering their women. It is a proven fact that without empowering the half of the population, a country cannot achieve prosperity in any field. Several governmental and non-governmental organizations are working intensively on women's empowerment issue, but the United Nations (UN) contributions are above all, as its charter ensures the basic rights of women. During the last two decades, the UN has held many conferences, seminars and workshops on women rights to launch a global strive. A number of the UN agencies are working on this issue, but most effective work on women's empowerment has been carried out by the United Nations Development Program (UNDP). It works throughout the world by advocacy, partnerships, and provides technical support and financial aid to government and non-governmental organizations. In Pakistan, women are 51.73 percent of the total population. The condition of female population specifically in rural areas is adverse. Women are deprived of their basic human rights, and the literacy ratio among women is also alarmingly low. Being a developing state, Pakistan depends upon financial aid and technical support from international agencies. After the $18^{\text {th }}$ amendment to the Constitution, provinces receive all sorts of aid directly from the donor agencies. The UNDP operates throughout the country known as "the UNDP Pakistan". Because of dire situation in rural areas, the UNDP is working for rural uplift. This study has highlighted the socio-economic impacts of UNDP initial program on women in detail.
\end{abstract}

Keywords: UNDP Projects, Pakistan, Rural Punjab, Socio-Economic Women Development

\section{Introduction}

Women's empowerment and gender equality fall under Millennium Development Goals (MDGs). All the work of the UN agencies particularly the UNDP is in the direction of meeting these MDGs. The MDGs are the most lucrative worldwide anti-poverty step taken in the history. Under these continuous efforts, 
significant and substantial development has been put forward to accomplish many targets that include halving the number of people living in extreme poverty and the proportion of people without sustainable access to improved sources. A significant decline in the proportion of urban slum dwellers has been seen. Remarkable gains are made in the fight against violence against women. Visible improvements have been observed in all health areas as well as in primary education of women. The achievement of the MDGs has been uneven among countries. The UNDP is working hard through expediting the actions so that MDGs can be achieved and drive the world for a striving and inspirational post-2015 development framework. It is the time for the UNDP to speed up efforts to build sustainable and secure environment for women [1]. The UNDP promotes transformational change by fostering strategic partnerships with national counterparts in federal, provincial and regional governments, civil society and the local and international community. The UNDP is helping Pakistan to coordinate activities on behalf of the UN's development system since 1960s. Its outstanding and neutral presence in Pakistan is a platform upon which trust is built. It forgoes constructive relationships and devises practically integrated responses with national and local partners which make it ideally positioned to take the lead in building capacities for sustained development. Pakistan is one of the eight countries which are selected for "One UN Pilot Program" that aims to provide development assistance in a more coordinated way. The UNDP leverages its comparative strengths by working through its national and local networks. It links ideas and best practices to develop localized solutions that support transformative change in Pakistan's development status [2]. The UNDP Pakistan has helped to attract aid and proper use of aid in effective manner while promoting the protection of human rights, capacity development and the empowerment of women. The agency has the highest standard of accountability, transparency and integrity in monitoring and evaluation of its programs, human resources, procurement and financial management procedures. It has facilitated the provision of gender justice and protection services to nearly 60,000 women across the country. Over 8,000 households received energy efficient cooking and heating equipment under environmental initiatives. The UNDP has strengthened peace and development through livelihoods and cash-for-work programs, community infrastructure rehabilitation, social cohesion and peace building activities. Early Recovery Program benefited more than 4.8 million people in 3,811 villages which were affected by the floods. Pakistan has adopted 16 targets and 41 indicators towards achieving the Eight Goals of the MDG's including women empowerment's goal. Time series data available for 33 of these indicators reveal that Pakistan is on track to achieve the targets on nine indicators, whereas its progress on 24 indicators is off the track. In the MDGs area of promoting gender equality and empowering women, Pakistan has achieved one of the highest ratios of women parliamentarians in the South Asia Region. The proportion of women in the national parliament (National Assembly and Senate) stands at 22.2 percent. It can also be noted that on three out of the four indicators related to MDG 3, progress is lagging. These three indicators include the GPI for youth literacy, secondary and primary education [2]. 


\section{Social Impact of the UNDP's Work}

\section{Women Representation and Contribution in Politics}

Women in Pakistan are deprived of their political rights. Especially, in rural areas they are refrained from participating in country's political process as voters. In rural areas, feudal system has barred women from voting, or taking part in election as candidates. Without the participation of women in electoral process, it causes serious doubts on the legitimacy of the election, as women account for more than 50 percent of the total population. Political empowerment can be achieved by increasing the number of seats in legislative assemblies. Pakistan has much better representation of women in assemblies and in local bodies as compared to the region. Assemblies should seek an increase in women representation in local bodies as well. But they have less representation in governments in as compared to assemblies. Pakistan has shown remarkable performance in recent years in terms of women participation in political arena, particularly with the reservation of almost 21 percent seats for them in the parliament. The ratio of vote casting among women is high in rural areas than urban areas. Same is the case with women candidates as majority of them contests from the rural areas. Legal reforms and the allocation of reserve seats in parliament have brought an improvement in women's political participation. A strong forum for vigorous support to women issues has emerged by this women parliamentarians' caucus. On the other hand, the transparency in an electoral system is very important for the sustainable development of any country. Credible and sound leadership emerges through the transparent electoral system which devises effective policies for country's development. The polling staff in Pakistan is not trained on the higher standards. Therefore, Election Commission of Pakistan (ECP) improved electoral system by seeking the help of the UNDP. The UNDP has laid its support to strengthen the ECP to enable it to hold credible, transparent and inclusive elections. The UNDP Pakistan supported the ECP in the training of 330,000 polling staff officials to ensure credibility of the polling process for the 2013 General Elections and more than 18,000 police officials were trained in election security. Around 40 million people were reached through a voter education campaign through the electronic, print and social media, and civil society organizations [3]. For the first time in Pakistan, an election result database was created containing results from polling stations. It also educated one million voters emphasizing women voters to exercise their right of vote given under the constitution. Women often waste their votes because they are not properly trained. The UNDP carried out training sessions to properly educate them so that they can play their role in political system of the country. Under these efforts a sharp increase in women voter is seen in 2013 general elections [4]. The vote casting ratio increased to 58 percent in 2013 as compared with 2008 which stood at 48 percent [5]. A woman named Zameer Akhtar, 28, had a maiden participation in the electoral process of 2013. As a part of a joint family it wasn't easier for her. The UNDP's advocacy campaign and due to lack of public confidence in previous elections she was compelled to participate in election and election trainings organized by the UNDP. "Our vote is our voice. If we do not vote, we will not get the leadership that we need to reduce inflation, eradicate poverty and provide access to good quality 
education," said Zameer Akhtar. This shows that women were inspired to vote under different campaigns from the UNDP and ECP [6]. In 2008 elections, 179 women contested for general seats. Whereas in Punjab 69 women contested for provincial seats and 47 for national assembly from Punjab (The Researchers, 2008). Talking about 2013 elections, 448 women contested for general seats from which 169 contested for general seats from Punjab and 116 for provincial assembly [7]. These statistics show a surge in women participation in politics and this number may rise with each of upcoming election as every eve of election is bringing more and more women candidates to contest for elections on general seats and more votes casting ratio among them.

The table 1 shows the active participation of women in political arena of the country which is on the rise.

Table 1

Political Participation of Women

\begin{tabular}{|l|c|c|}
\hline Indicators & $\mathbf{2 0 0 8}$ & $\mathbf{2 0 1 3}$ \\
\hline Vote Caste Ratio (National) & 43.65 & 55.26 \\
\hline Vote Caste Ratio (Punjab) & 47.55 & 58.62 \\
\hline Polled Votes (National) & $35,637,072$ & $46,217,482$ \\
\hline Polled Votes (Punjab) & $21,442,088$ & $28,760,265$ \\
\hline $\begin{array}{l}\text { Total Female Voters } \\
\text { (National) }\end{array}$ & $13,606,360$ & $37,561,432$ \\
\hline Total Female Voters (Punjab) & $20,006,958$ & $21,561,633$ \\
\hline $\begin{array}{l}\text { No. of seats constituted by } \\
\text { women for National seats } \\
\text { from Punjab }\end{array}$ & 47 & 180 \\
\hline $\begin{array}{l}\text { No. of seats constituted by } \\
\text { women for Provincial seats } \\
\text { (Punjab) }\end{array}$ & 69 & \\
\hline
\end{tabular}

Source: Election Commission of Pakistan.

\section{Curbing Violence Against Women}

Women in Pakistan face violence persistently across religion, class, and ethnicity. Therefore, their health, education and employment are affected by this. The empowerment of women in real terms needs provision of a suitable atmosphere free from violence. The UNDP has launched a Gender and Justice Project to establish a fund for research and other steps for the help of such women. The UNDP launched many advocacy and awareness campaigns to highlight the issue with the help of seminars and theatre shows. Medical officers, religious scholars, factory workers, police officers, para-legal workers, civil society representatives, media professionals are approached for their contribution in eradicating this menace. The UN has declared five goals to end violence against women (UN, 2008), so the UNDP is committed to work for eradication of this menace. Twenty referral, legal aid and counseling centers were established across the country. About 1,900 women got legal aid and over 33,000 women got counseling/referral services. Over 1000 women were benefited from these services for social rehabilitation [8]. Awareness campaigns discouraged and thwarted many men of victimizing women. 


\section{Empowerment in Public Offices}

In Pakistan women are unaware of their legal and constitutional rights. The UNDP started a project to give them proper awareness about these rights which aimed at empowering women in public offices so that they may have better understanding of their legal and constitutional rights. The concerns are raised in the policy agenda and are addressed through public policy. Women are able to work confidently after knowing that they can charge men who harass them. If women have proper information about these rights, they can survive with confidence in working atmosphere [4].

\section{Energy (Natural Gas) Shortage in Rural areas}

Pakistan is facing severe energy crises. In rural areas availability of a cheap energy for cooking is of utmost importance. Cooking is considered as a primary duty of women. Woods and animal dung are main source of energy for the cooking. Women have to bring these things several miles away from home, in some cases if they do not own lands or cattle. LPG is only alternative to firewood. But LPG prices have observed a sharp increase in recent years. Other than this, LPG is only available in cities or in their suburbs. Government faces hassle in providing natural gas to villages due to the shortage. It is intricate to meet growing demand of gas, as Iran-Pakistan gas pipeline is in disarray. The best solution is to establish Bio-gas plants in these areas. Bio-gas plants are not so much expensive. Animal dung can easily be utilized for running these plants. It is hard for the government to provide natural gas facility to all rural areas. Therefore, the UNDP in collaboration with Government of Pakistan started a Pakistan Domestic Biogas Program to establish such plants in rural areas. There is a huge potential of domestic biogas in Pakistan as water, animal dung, the availability of construction materials, suitable temperature, enough space for plant installation and availability of human resources for the construction of plant are available in sufficient numbers. In total, 70 plants were established [8]. A positive impact on the life of the rural dwellers was seen as these plants improved their livelihoods and quality of life by saving their expenditures and physical energy from collecting woods for fuel far away from their homes.

\section{Disaster Management of the UNDP}

In 63 years, Pakistan has never experienced such ferocious floods as it saw during August 2010. The impact on the life, property and livestock was devastating. The damages put the country to a stage that takes tens of years to recoup. Hundreds of villages were swept away in Punjab. Standing crops, animal farms and infrastructures damaged badly. Livestock, one of the major sources of income for rural families was badly affected. The impact on the life, property and livestock was devastating. Millions of the people lost their homes and income sources. The UNDP carried out its largest of relief efforts across the country. It set relief camps which provided shelter and food to flood effectives. It also carried out surveys for the accurate assessment of the loss through which government made data for starting relief efforts and reach out people more effectively. The UNDP provided clean drinking water, arranged medicines in medical camps and provided fodders for 
animals [9]. Raw material was also provided to women as they deadly needed it to finish products in home-based industry to earn their livelihood. Due to these efforts women who were more vulnerable to calamities were able to earn livelihood and arranged fodder for their animals.

\section{Improvement in the Education sector}

Literacy rate in Pakistan is very poor in comparison with neighboring countries and it worsens among women despite of persistent efforts in this regard. Women in rural areas are not allowed to study or excel in it. The primary task considered for them is to remain intact within the houses and perform household duties like cooking, cleaning etc. There are other lots of factors which hinder women access to schools. The UN has launched "Education for All" program which has an objective to achieve universal and free compulsory education up to class ten. Article 25-A of the Constitution makes the provision of education free and compulsory for all children aged five to 16 years. The UNDP helped in establishing an Inter-Provincial Forum on Education with federal and provincial representation, and organized seminars to foster provincial-district coordination. The initiatives on Education carried out a number of interventions in 2011, in collaboration with government counterparts, to increase enrolment and retention in schools, particularly of girls, and to foster a better learning environment and quality teaching for students [10]. Efforts of the UNDP included provision of equipment and learning materials and support for improved teacher training and provision of incentives. During floods many school and other education facilities were restored so that a number of children would be able to continue their education. As part of efforts to tackle child labor, the UNDP supported the inclusion of non-formal basic education in government initiatives to rehabilitate child laborers. Many girls work in houses as slaves in other child labor categories for this the UNDP supported education system strengthening through capacity development initiatives targeting policy makers, sector managers and planners at provincial and district level. The literacy level of rural women in Punjab has a continuous one percent increase from 2006 to 2011, which was 37 percent in 2006 [11]. It shows that initiatives are result oriented, but it demands more and more efforts. As a result of these efforts literacy rate among rural women in Punjab has increased to 42 percent in 2011 (see table 2) [12].

Table 2

Education Statistics of Women

\begin{tabular}{|l|c|c|c|}
\hline Indicators & $\mathbf{2 0 0 2}$ & $\mathbf{2 0 0 7}$ & $\mathbf{2 0 1 2}$ \\
\hline Literacy Rate (National) & 31 & 41 & 46 \\
\hline Literacy Rate (Punjab) & 36 & 48 & 51 \\
\hline $\begin{array}{l}\text { Literacy Rate } \\
\text { (Rural Punjab) }\end{array}$ & 28 & 37 & 53 \\
\hline $\begin{array}{l}\text { Net school enrollment } \\
\text { (National) }\end{array}$ & 48 & 51 & 59 \\
\hline $\begin{array}{l}\text { Net school enrollment } \\
\text { (Punjab) }\end{array}$ & 45 & 48 & \\
\hline
\end{tabular}

Source: UNDP Pakistan, Punjab MDG Report 2011. 


\section{Improvement in Health sector}

Women face the most health-related issues along with their infants. A weak mother gives birth to a weak child which leads to an unhealthy nation. The health condition of rural women remained depressive. In some practices women are not allowed to appear before male doctors because rural centers lack female doctors. During 2011, the Joint Program of the UNDP on Health and Population made considerable progress in promotion of universal coverage of $\mathrm{MNCH}$ and $\mathrm{FP} / \mathrm{RH}$ services, by raising health care and vaccinating awareness among the public, specifically among pregnant and lactating women. Provision of equipment and training of health care providers contributed to better nutritional outcomes for infants. Micronutrient deficiencies were addressed through Vitamin A supplementation and promotion of salt iodization. Communicable disease control was promoted through administration of almost 190 million doses of polio drops, and various initiatives to control TB, hepatitis and malaria [4]. The UNDP under this program launched a combination of advocacy, service provision, capacity building and resource mobilization was carried out to contain HIV infection and provide HIV care for key affected and at-risk populations. These steps improved health of number of rural women. In the region, Pakistan has highest maternal and infant mortality rates which are needed to be reduced. The below mentioned figure reflects that efforts are result oriented (table 3 ).

Table 3

Health Statistics of Women

\begin{tabular}{|l|c|c|c|}
\hline Indicators & $\mathbf{2 0 0 2}$ & $\mathbf{2 0 0 7}$ & $\mathbf{2 0 1 2}$ \\
\hline $\begin{array}{l}\text { Maternal Mortality Rate } \\
\text { (National) }\end{array}$ & 350 & 380 & 260 \\
\hline $\begin{array}{l}\text { Maternal Mortality Rate } \\
\text { (Punjab) }\end{array}$ & 219 & 227 & 211 \\
\hline Fertility Rate (National) & 4.8 & 4.0 & 3.4 \\
\hline Fertility Rate (Punjab) & 4.9 & 3.5 & 3.7 \\
\hline
\end{tabular}

Source: Pakistan Social and Living Measurement Report 2012.

\section{Provision of Clean Drinking Water}

Getting clean water in Pakistan is an intricate problem in the remote areas. Women have to fetch water from several miles as this is considered as a primary duty of women. In flood affected areas the situation worsened more as getting a clean drinking water was a hard task. Women and children were vulnerable to water porn diseases because of drinking unsafe water. The UNDP installed 200 water pumping solar plants. It provided thousands of families and animals with clean and safe drinking water and saved energy of thousands of women that would have used collecting unsafe drinking water from miles away [10].

\section{Training of Female Legislatures}

In the male dominant parliament, it is difficult to devise law and policies which truly reflect women needs because males do not understand the real issues of women, so it is important to increase women representation in the parliament. 
Although in recent years women participation in political arena has increased but it is further needed to properly guide and train them so that they can raise their voices and able to pass bills that address women issues in the real terms. This increased representation of women in assemblies is not an old phenomenon, as in the 20th century women hardly had any representation in the assemblies. The UNDP started a project to empower women in legislature and guide them in legislative process. So, these newly elected legislators have not experienced or understand legislative process. Only those women legislators can be able to understand women issues well who are properly trained to it. It is at earnest to train them about this complex process. These women legislators do not have sufficient knowledge how to participate effectively in legislation process for betterment of women therefore training and seminars proved helpful in improving their knowledge of laws and proceeding of assemblies. These women assembly members were able to introduce bills with properly debated, and finally were able to pass them from respective assemblies. Many women legislators who were interviewed were of the view that this training exercise enhanced their capabilities and were able to understand legislation process much efficiently. In many areas of Pakistan, women have deprived of the right to vote. Even if women were allowed to vote they cannot vote on their own, in fact they have to follow the decision of their males. On the other hand, the UNDP positive steps also helped in increasing the voting ratio of female in General Elections May 2013.

\section{Economic Impact of the UNDP's work}

\section{Improvement in Agriculture sector}

Agriculture practices cannot be undertaken on such lands. Farmers, including women or poor women, who used to work in such lands lost their substantial income. However, some of the degraded lands were successfully rehabilitated by the use of gypsum. It needs more practical steps to achieve the goals. Some of agriculture lands in rural areas have been waterlogged due to salinity and the ability of absorbing water is almost ended. The poor farmers including women who own nominal lands suffered heavy financial losses due to this. They were helpless as agriculture lands were only source of their income. The UNDP launched a Biosaline project for the rehabilitation of those lands which were affected by salinity and water logging in rural areas of three districts Sargodha, Hafizabad and Jhang. So that such lands can be made cultivatable and useful for poor farmers which aimed at poverty alleviation. Women farmers were also provided alternative choices to make these lands useful. They are now able to cultivate lands to meet their needs. Some of them established kitchen gardening, some of them made fishponds etc.

\section{Promotion of Fisheries for Economic Benefits}

Women have a great potential in fisheries sector, as it is beneficial in dual ways; firstly, it provides food, and secondly, it brings economic benefits. Fish has become a modern food commodity. Its demand is on high, hence becoming a common food item. There has been no significant work by the UNDP in this sector. 
Rural areas are the lucrative for this business especially those areas where lands are affected by salinity hence cannot be used for cultivation. In rural areas fish farming is reasonable resource of income generation. The appropriate lands are already available in rural areas. Fish can also useful in getting enough food. Uncultivated lands are most suitable for fish farming where normal agricultural practices cannot take place. In collaboration with Food and Agriculture Organization, the UNDP provided farmers including women with equipment to enhance pond water, establishing fish farm training centers, construction of ponds, improving hatcheries and fish nursery units and up graded the previous facilities [13]. The poor women were able to generate income and food for themselves. Fisheries is easy for women as it does not demand any hard exercise, women can meet food demands as well as use it for economic benefits.

\section{Employment Generation}

The best way to empower women is to eradicate the poverty and minimize their dependency on men or society. This can be achieved by providing them employment opportunities, so that they can become independent. It may enhance women position and status in their families, and society as well. Women in rural areas are less educated, so they are left with those tasks which are associated with villages, like stitching, farming, livestock and home-based industries, as education is not necessary in these fields. For this purpose, the UNDP launched two projects; one is in livestock, and second aimed at the garment industry. The livestock or dairy project aims at selling animal or animal meat and their milk for economic benefits. Women have a great potential in the garment industry, from collecting cotton from fields to the finished product. Therefore, garment industry can provide best opportunities to earn income. The UNDP arranged employment opportunities to hundreds of poor women in garment industry under a GEN-PROM project by developing their skills through trainings. A significant positive impact of the project is seen by increased household income and standard of living. Women started to get 6,000 Rs monthly income. On the other hand, garment industry also benefitted by these skill full workers. This project has a positive impact on women as it provided relevant skills to poor women that were in demand in the garment industry, resulting in the employment of women and generated healthy income. Outputs of the GENPROM contribute to the country's decent employment and poverty alleviation strategy as well as promotion of gender equality. Share of women in non-agriculture sector has increased to 11.03 in 2011 from 10.93 percent in 2005 [14]. In rural areas it is difficult to provide employment opportunities to women other than agriculture, but the best alternate to it is a livestock sector. The UNDP started a projected based on livestock for the economic empowerment of women. The project has brought significant change in the lives of these women and their families. In the areas where women are not even entitled to make decisions, they have turned in to self-employed, socio-economically empowered women. With the extra income their children are now enjoying good food and education facilities, whereas their livestock are becoming healthier as well. The impact of the UNDP's work is somehow limited in general because only those respondents take benefits which are focus of a particular project. All of these projects are of significant importance. Unfortunately, Pakistan is 
not a welfare state in a practical term. The government of Pakistan lack funds to benefit each entity of the population. Therefore, a space is created for others, due to which many national and international organizations are contributing in improving living standard of people of Pakistan. The UNDP has occupied this space, but it cannot benefit a whole community because of its limited scope. But government can enlarge these benefits to whole community by making agency's successful projects and programs as a part of its policies. The UNDP projects can act as a role model for the government and other organizations. Therefore, collaboration of government departments with the UNDP is of very importance. This relation can prove positive for tackling this menace.

\section{Conclusion}

The UN founded it agencies for the welfare of depressed factions of the world population. It has declared women empowerment and gender equality as its millennium goal which is to be achieved till 2015. The UN has formed a special sub-agency "UNWOMEN" in 2010 to address the issues related to women more effectively. This shows the importance of women's issues for the UN. The UNDP is a development organization of the UN which is responsible for the development and implementing the UN's public welfare agenda. The role of the UNDP in raising women standard of life is of a paramount importance. The UNDP in Pakistan as "UNDP Pakistan" has been working on women issue since 1960. There are visible impacts of the UNDP work on socio-economic development of women in general and rural in particular. The UNDP has tried to address all the issues with appropriate solutions which could have resulted in betterment of their lives. It can be concluded that the UNDP laid its significant contribution in uplifting socio-economic status of women in rural areas of the Punjab in particular and entire country in general. The UNDP has a capability of implementing any project anywhere in the country even implemented abroad as it doesn't require any diplomatic prerequisites. Hence, it is important for the government of Pakistan to devise and implement women-oriented welfare projects under the policy guidelines of the UNDP. The positive nexus between government and the UNDP is important for the success of a programs and projects. The UNDP has played a significant contribution in improving socioeconomic well-being of women in rural areas. The UNDP is well equipped, more skilled, and has a lot of experience in resolving the issues of public affairs than the governments of the developing states. A major obstacle is the limited sphere of the agency, due to which it cannot benefit a whole population. Therefore, the best solution to it is the collaboration with government, which has the capability to implement a result-oriented model (from the UNDP) on a larger scale. Concerned government departments can benefit themselves with the useful inputs from the UNDP. Although, this study has been carried out in the light of the UNDP projects, but these recommendations are not only helpful for this particular agency, but also for the government and other non-governmental setups, which are working on the same issue. These suggestions are presented to the higher authorities. The government has the appropriate machinery to implement these programs. All nongovernment organizations need government support to initiate their projects and 
programs in an effective manner. Gender equality can be ensured by capacity building of governments and organizations working with civil society. The UNDP must be given a chance to voice its inputs about women concerns and priorities in decision making. The UNDP must increase capacity building of public institutions, so that they can respond effectively to these inputs. Skill enhancement of national organizations and institutions, such as the National Commission on the Status of Women and the Ministry of Women's Development is also required for ensuring their effective participation in national planning process, monitoring execution and upholding accountability systems for the gender equality. The corruption is a big menace in Pakistan. Corruption roots are embedded in the Pakistani society. The governments, judiciary, civil society and others are victim to it. Hence, it is important for the UNDP to make sure that the funds provided to governments and local NGOs must be properly utilized. Each penny must be utilized in the projects.

\section{REFERENCES}

[1] The Millennium Development Goals Report 2013. United Nations. New York: UN; 2013.

[2] UNDP Pakistan Annual Report 2011. UNDP Pakistan. Islamabad: UNDP Pakistan; 2011.

[3] Electoral cycle support to the Election Commission of Pakistan. UNDP Pakistan. 2013. URL: http://www.pk.undp.org/content/pakistan/en/home/operations/projects/womens_empowerment/project_sample/. Accessed: 02.04.2020.

[4] Sharp Increase of Women Voters in Pakistan's Recent Elections. UNWOMEN. 2013. URL: http://www.pakistanaffairs.pk/threads/54641-Sharp-Increase-of-Women-Voters-in-Pakistan\%E2\%80\%99s-Recent-Elections. Accessed: 02.04.2020.

[5] Turnout Comparison of Election Result 2008 \& 2013 (National Assembly). Election Commission of Pakistan. 2013. URL: http://ecp.gov.pk/Misc/GE-2013-Graphs/02_na_turnout_comparison.png. Accessed: 03.04.2020.

[6] United Nations Development Programme. Goodwill ambassadors. 2013. URL: http://www.undp.org/content/undp/en/home/ourwork/goodwillambassadors.html. Accessed: 03.04.2020.

[7] 448 Women Candidates Contesting on General Seats. Immamudin Business Recorder. 07.05.2013.

[8] From Words to Action: An Introduction to GJP Supported Initiatives to Combat Violence Against Women (VAW). UNDP Pakistan. Islamabad: UNDP Pakistan; 2007.

[9] 2010 Floods in Pakistan - A Race Against Time! UNDP Pakistan. Islamabad: UNDP Pakistan; 2010.

[10] Part II: One Programme Progress in Pakistan. Pakistan One UN Programme Report. Islamabad: The United Nations System in Pakistan Publication; 2012: 20-47.

[11] Pakistan Social and Living Standards Measurement Survey (Pslm) 2010-11 Provincial / District. Islamabad: Pakistan Bureau of Statistics, Government of Pakistan; 2011.

[12] About UNDP in Pakistan. UNDP Pakistan. 2013. URL: http://www.pk.undp.org/content/pakistan/en/home/operations/about_und.html. Accessed: 05.04.2020.

[13] Project Punjab 2006. Soroptimist. 10.12.2006. URL: http://www.soroptimistinternational.org/our-projects/december-10appeal/project-punjab. Accessed: 05.04.2020

[14] Shaheed F. Preface in Women in Pakistan: General Conditions, Approaches and Project Proposals for the Development of Vocational Qualification of Women in the Province of Punjab. Lahore: Vanguard Books Limited; 1992. 
[15] About UNDP in Pakistan. UNDP Pakistan. 2013. URL: http://www.pk.undp.org/content/pakistan/en/home/operations/about_und.html. Accessed: 06.04.2020.

\title{
Article history:
}

The article was submitted on 17.04.2020.

The article was accepted on 01.06.2020.

Научная статья

\section{Влияние инициированных ПРООН проектов на социально-экономическое развитие женщин: исследование сельских районов Пенджаба, Пакистан}

\author{
Р.Д. Нисар
}

Центральный китайский педагогический университет

№ 152, Лоую Роад, 430079, Ухань, Хубэй, Китайская Народная Республика

Аннотация. Женщины составляют половину всего населения мира, при этом их положение по всему миру резко различается. Проблема расширение прав и возможностей женщин в XXI веке приобрела гораздо большую важность, чем прежде. Является доказанным фактом то, что без расширения возможностей половины населения страна не может достичь процветания в любой области. Целый ряд правительственных и неправительственных организаций интенсивно работают над вопросом расширения прав и возможностей женщин, не вызывает сомнений особый вклад Организации Объединенных Наций $(\mathrm{OOH})$ в этой области, прежде всего заключающийся в том, что ее устав гарантирует основные права женщин. В течение последних двух десятилетий ООН было проведено много конференций, семинаров и практикумов по правам женщин в рамках глобального движения. Ряд учреждений ООН работают над этим вопросом, но наиболее эффективная работа по расширению прав и возможностей женщин была проведена Программой развития Организации Объединенных Наций (ПРООН). Она работает по всему миру путем пропагандирования, партнерства и предоставляет техническую поддержку и финансовую помощь правительственным и неправительственным организациям. В Пакистане женщины составляют 51,73\% от общей численности населения. Положение женского населения, особенно в сельской местности, является в целом неблагоприятным. Часто женщины лишены своих основных прав, и уровень грамотности среди женщин также угрожающе низок. Будучи развивающимся государством, Пакистан зависит от финансовой помощи и технической поддержки со стороны международных агентств. После 18-й поправки к Конституции провинции страны получают всевозможную помощь непосредственно от учреждений-доноров. Сегодня из-за тяжелой ситуации в сельской местности страны «ПРООН Пакистан» работает в том числе над подъемом уровня жизни сельского населения. В этом статье подробно освещены социально-экономические последствия программы ПРООН для женщин.

Ключевые слова: проекты ПРООН, Пакистан, сельский Пенджаб, социально-экономическое развитие женщин

\section{История статьи:}

Статья поступила в редакцию: 17.04.2020.

Статья принята к публикации: 01.06.2020. 


\section{Информация об авторе:}

Рана Даниш Нисар - аспирант Школы политики и международных исследований Классического университета центрального Китая (KHP) (ORCID ID: 0000-0002-13545144) (e-mail: ranadanishnisar@gmail.com).

\section{Information about the author:}

Rana Danish Nisar - PhD Student of the School of Politics and International Studies, Central China Normal University (People's Republic of China) (ORCID ID: 0000-0002-13545144) (e-mail: ranadanishnisar@gmail.com).

\section{Для цитирования:}

Nisar R.D. Impact of UNDP's Initiated Projects on Socio-Economic Development of Women: A Study of Rural Punjab, Pakistan // Вестник Российского университета дружбы народов. Серия: Государственное и муниципальное управление. 2020. Т. 7. № 3. С. $272-$ 284. DOI: $10.22363 / 2312-8313-2020-7-3-272-284$

\section{For citation:}

Nisar R.D. Impact of UNDP's Initiated Projects on Socio-Economic Development of Women: A Study of Rural Punjab, Pakistan. RUDN Journal of Public Administration. 2020; 7 (3): 272-284. DOI: 10.22363/2312-8313-2020-7-3-272-284 